\title{
PREVALENCE AND BACTERIAL ETIOLOGY OF MASTITIS IN SMALL RUMINANTS IN TORO LOCAL GOVERNMENT AREA, BAUCHI STATE, NIGERIA
}

\author{
Danmallam F.A., Postgraduate student \\ Pimenov N.V.*, Doctor of Biological Sciences, Professor \\ Moscow state Academy of Veterinary Medicine and Biotechnology, Moscow, Russia \\ Ngulukun S.S., Head of Department \\ Mwankon S.E., Researcher \\ Bacterial Research Department, National Veterinary Research Institute, Vom, Nigeria \\ *E-mail: pimenov-nikolai@yandex.ru
}

\begin{abstract}
A study was conducted at Toro Local Government Area of Bauchi State, north-eastern Nigeria to assess the prevalence of clinical and subclinical form of mastitis in lactating small ruminants - sheep and goat and identify causative agents. A total of 348 mammary gland secretion (milk) samples comprising 108 and 244 from sheep and goats, respectively, were screened for evidence of mastitis. The overall prevalence of subclinical mastitis was found to be $16.7 \%(18 / 108)$ and $24.6 \%(60 / 244)$ in sheep and goats, respectively. The overall prevalence of clinical mastitis was found to be $5.6 \%(6 / 108)$ and $5.7 \%(14 / 244)$ in sheep and goats, respectively. California mastitis test (CMT) positive milk samples were subjected to bacteriological examination and found to be that in both sheep and goats, the predominant organisms responsible for mastitis were Staphylococcus aureus, followed by Escherichia coli, Streptococcus spp. and coagulase negative Staphylococcus and the least isolated microorganisms of different species including Enterobacter cloacae, Klebsiella oxytoca, Klebsiella pneumonia, Morganella morganii, Salmonella typhimurium, Proteus vulgaris, Citrobacter freundii and Bacillus cereus. Therefore, it can be concluded that mastitis is an important disease affecting the productivity of small ruminants and quality of their product (especially milk) for their kids and consumers, hence measures need to be taken to control the disease.
\end{abstract}

\section{KEY WORDS}

Prevalence, small ruminant, mastitis, etiology, bacteria.

Small ruminants play an important role in the nutrition and income of people worldwide. It has been estimated that there are more than 460 million goats worldwide producing about 4.50 million tons of milk and 1.20 million tons of meat annually. Small ruminants in Africa produce only $14.0 \%$ of the world's milk [7].

Ogbeh A. (2016) spoke that, according to 2011 impressive statistics of National Agricultural Sample Survey indicated that Nigeria was endowed with an estimated 41.3 million sheep and 72.5 million goats, which had made Nigeria number one in livestock production in Africa [11], with the average daily milk production of 2.3 liters day ${ }^{-1}$.

Goat milk is highly nutritious and has a similar nutritional profile to those of human's breast milk [6]. But milk quality may be affected by bacterial contamination of mammary gland, which causes clinical and subclinical mastitis [8].

Mastitis is a parenchymal inflammation of the mammary gland, characterized by physical, chemical and usually bacteriological changes in milk and pathological changes in glandular tissues [5]. The disease is caused usually by pathogenic bacteria and other microbes entering the gland through the teat duct [15]. Hence results in severe economic losses from reduced milk production, treatment cost, increased labor, milk withheld following treatment and premature culling [10]. 
In Nigeria several pathogens were isolated from cases of small ruminants mastitis, these include: S. aureus, S. epidermidis, Corynebacterium spp., Str. agalactiae, Str. dysgalactiae, Micrococcus spp., Bacillus spp., Klebsiella spp. Pasteurella spp., Pseudomonas spp., Actinobacillus spp. and Alcalingenes spp. [1].

Review of literature yielded very limited information on the diseases of small ruminants in Nigeria, particularly mastitis which is universally recognized as one of the most costly diseases in the dairy industry. This study was undertaken to isolate and identify major bacteria pathogens in the mammary gland secretion of mastitic sheep and goats.

\section{MATERIALS AND METHODS OF RESEARCH}

This survey was carried on 54 sheep and 122 goats with 108 and 244 quarters respectively from Magama, Unguwan Baro, Toro, and Tilde, located in Bauchi State, northeastern part of Nigeria, were screened for mastitis using the California mastitis test (CMT) reagent. In the study areas, especially sheep are preferred animals next to cattle, which are manage under an extensive management system by an individual farmers. Farmers who own more than 5 sheep and goats keep their animals in barns while those who own less than 5 small ruminant animals keep them in their own houses.

To detect mastitis, physical examination including observation and palpation of the udders for symmetry and size, indurations and fibrosis, milk consistency and colour change, and any visible abnormalities were recorded. Sing of inflammation, lessions on the udder/teat skin, and presence of ticks were observed. Udders and teats were cleaned and dried before sample collection. The teats were disinfected with $70 \%$ alcohol before sample collection. The first few streams of milk were discarded and ten (10) ml udder half milk samples were collected in labeled sterilized test tubes and immediately transported in an icebox with ice to the laboratory for microbiological analysis.

Clinical mastitis was detected by gross signs of udder infection during physical examination and abnormal milk whereas subclinical mastitis (SCM) was recognized by apparently normal milk and positive (CMT).

The results for CMT were recorded as 0 , trace, $1+, 2+$ and $3+$. In this study, CMT scores of 0 and trace were considered as negative while CMT scores of $1+, 2+$ and $3+$ were taken as indicators of subclinical mastitis.

The isolation and identification of bacterial pathogens were performed according to the procedure described by Quinn et al. (2002). In Brief, $0.1 \mathrm{ml}$ milk sample was cultured on blood agar, nutrient agar, MacConkey agar and Brucella agar base. The inoculated plates were incubated at $37^{\circ} \mathrm{C}$ aerobically for 24-48 hours, while those on Brucella agar were incubated at $37^{\circ} \mathrm{C}$ anaerobically for 7 days. The bacterial pathogens were identified by morphology, haemolysis, Gram staining and biochemical test like catalase, oxidase, coagulase, reaction on SIM (sulphite, indole and motile) medium and fermentation of sugars.

\section{RESULTS OF STUDY}

Studies on the finding of the spread of mastitis among lactating small ruminants were carried out in the sheep and goat herds in cities of Toro Local Government Area of Bauchi State of the Republic of Nigeria. The results are shown in Table 1.

The data presented in Table 1 show that in the studied areas, regardless of the form of the disease, in the year mastitis was recorded from 15.4 to 18.8 and 14.3 to 30.4 in sheep and goats, respectively.

Out of the total of 108 samples examined, mastitis was diagnosed in 24 mammary gland secretion of sheep, which is $22.2 \%$. Out of these (24 affected samples), subclinical mastitis was diagnosed in 18 samples, which is $16.7 \%$, and clinically form - in 6 udder halves $-5.6 \%$. At the same time of the 244 examined udder halves secretion of goats, mastitis was found in 74 samples, which is $30.3 \%$. Thus subclinical mastitis was diagnosed in 60 samples, which is $24.6 \%$ and the clinically expressed form - in 14 samples $-5.7 \%$. 
Table 1 - The degree of prevalence of mastitis in small ruminants in Toro Local Government Area, Bauchi State, Nigeria

\begin{tabular}{|c|c|c|c|c|c|c|c|c|c|c|c|c|c|}
\hline \multirow{4}{*}{ № } & \multirow{4}{*}{ Name of town } & \multirow{3}{*}{\multicolumn{2}{|c|}{ Number of milking heads }} & \multirow{3}{*}{\multicolumn{2}{|c|}{ Number of test samples }} & \multicolumn{8}{|c|}{ Forms of mastitis } \\
\hline & & & & & & \multicolumn{4}{|c|}{ subclinical } & \multicolumn{4}{|c|}{ clinical } \\
\hline & & & & & & \multicolumn{2}{|c|}{ abs. } & \multicolumn{2}{|c|}{$\%$} & \multicolumn{2}{|c|}{ abs. } & \multicolumn{2}{|c|}{$\%$} \\
\hline & & $\begin{array}{l}\frac{0}{\phi} \\
\frac{\mathbb{1}}{\infty}\end{array}$ & $\begin{array}{l}\frac{0}{\pi} \\
\stackrel{0}{0}\end{array}$ & $\begin{array}{l}\stackrel{0}{\Phi} \\
\frac{\Phi}{\omega}\end{array}$ & 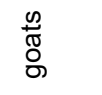 & $\begin{array}{l}\stackrel{Q}{\otimes} \\
\frac{\mathbb{L}}{\omega}\end{array}$ & $\begin{array}{l}\frac{0}{\pi} \\
\stackrel{0}{0} \\
\stackrel{6}{6}\end{array}$ & $\begin{array}{l}\frac{0}{\Phi} \\
\frac{\Phi}{\infty}\end{array}$ & $\begin{array}{l}\frac{\infty}{\pi} \\
\stackrel{0}{0}\end{array}$ & $\begin{array}{l}\frac{\varrho}{\Phi} \\
\frac{\Phi}{\infty}\end{array}$ & $\begin{array}{l}\frac{9}{\pi} \\
\stackrel{0}{0}\end{array}$ & $\begin{array}{l}\stackrel{0}{\Phi} \\
\stackrel{\Phi}{\omega}\end{array}$ & $\begin{array}{l}\frac{9}{\pi} \\
\frac{\pi}{8}\end{array}$ \\
\hline 1 & Magama & 13 & 21 & 26 & 42 & 4 & 6 & 15,4 & 14,3 & 1 & 2 & 3,8 & 4,7 \\
\hline 2 & Unguwan Barlo & 13 & 24 & 26 & 48 & 4 & 12 & 15,4 & 21,4 & 0 & 4 & 0 & 7,1 \\
\hline 3 & Toro & 16 & 51 & 32 & 102 & 6 & 31 & 18,8 & 30,4 & 3 & 5 & 4,9 & 5,9 \\
\hline 4 & Tilde & 12 & 26 & 24 & 52 & 4 & 11 & 16,7 & 21,2 & 2 & 3 & 8,3 & 5,8 \\
\hline & Total & 54 & 122 & 108 & 244 & 18 & 60 & 16.7 & 24.6 & 6 & 14 & 5.6 & 5,7 \\
\hline
\end{tabular}

From the data in the table 1 it shows that a particular danger is subclinical mastitis, occurring 3-4 times more often than the clinically expressed form of the disease.

Carrying out the bacteriological analysis on the scheme indicated previously (see Table 1) allowed obtaining the data on the microbial contamination of the affected sheep's and goat's mammary glands.

The results of bacteriological research allowed us to identify and partially characterize cultures of microorganisms in the secretions of the mammary gland. Their species composition is presented in Table. 2 .

Table 2 - The relative prevalence rate of various bacteria isolated from the milk samples of mastitis sheep goats

\begin{tabular}{|c|c|c|c|c|c|c|}
\hline \multirow{4}{*}{ Microorganisms } & \multicolumn{6}{|c|}{ Frequency and percentage of isolates } \\
\hline & \multirow{2}{*}{\multicolumn{2}{|c|}{ Clinical mastitis, no (\%) }} & \multirow{2}{*}{\multicolumn{2}{|c|}{ Subclinical mastitis, no (\%) }} & \multicolumn{2}{|c|}{ Total } \\
\hline & & & & & \multirow{2}{*}{$\begin{array}{c}\text { Clinical } \\
\text { mastitis } \\
\text { no (\%) }\end{array}$} & \multirow{2}{*}{$\begin{array}{c}\text { Subclinical } \\
\text { mastitis, } \\
\text { no }(\%)\end{array}$} \\
\hline & sheep & Goat & sheep & goat & & \\
\hline Staphylococcus aureus & $3(33.0)$ & $6(66.7)$ & $9(42.9)$ & $12(57.1)$ & $9(36.0)$ & $21(18.3)$ \\
\hline Staphylococcus auricularis & - & - & - & $2(100.0)$ & - & $2(1.7)$ \\
\hline Staphylococcus chromogenes & - & $1(100)$ & $1(25.0)$ & $3(75.0)$ & $1(4.0)$ & $4(3.5)$ \\
\hline Staphylococcus caprae & - & - & - & $3(100.0)$ & - & $3(2.6)$ \\
\hline Staphylococcus hyicus & - & - & - & $2(100.0)$ & - & $2(1.7)$ \\
\hline Staphylococcus epidermidis & $2(66.7)$ & $1(33.3)$ & $1(50.0)$ & $1(50.0)$ & $3(12.0)$ & $2(1.7)$ \\
\hline Streptococcus agalactiae & $1(33.3)$ & $2(66.7)$ & $5(31.3)$ & $11(68.8)$ & $3(12.0)$ & $16(13.9)$ \\
\hline Streptococcus dysgalactiae & - & $2(100)$ & $4(57.1)$ & $3(42.9)$ & $2(8.0)$ & $7(6.1)$ \\
\hline Streptococcus pluranimalium & - & - & - & $3(100.0)$ & - & $3(2.6)$ \\
\hline Streptococcus uberis & - & - & $4(80.0)$ & $1(20.0)$ & - & $5(4.3)$ \\
\hline Streptococcus ruminatorum & - & - & - & $3(100.0)$ & - & $3(2.6)$ \\
\hline Escherichia coli & $2(40.0)$ & $3(60.0)$ & $9(42.9)$ & $12(57.1)$ & $5(20.0)$ & $21(18.3)$ \\
\hline Enterobacter cloacae & - & - & - & $3(100.0)$ & - & $3(2.6)$ \\
\hline Klebsiella oxytoca & - & - & $2(66.7)$ & $1(33.3)$ & - & $3(2.6)$ \\
\hline Klebsiella pneumonia & $1(100)$ & - & $3(60.0)$ & $2(40.0)$ & $1(4.0)$ & $5(4.3)$ \\
\hline Morganella morganii & - & - & $1(25.0)$ & $3(75.0)$ & - & $4(3.5)$ \\
\hline Salmonella typhimurium & - & - & - & $3(100.0)$ & - & $3(2.6)$ \\
\hline Proteus vulgaris & - & $1(100)$ & - & $3(100.0)$ & $1(4.0)$ & $3(2.6)$ \\
\hline Citrobacter freundii & - & - & - & $2(100.0)$ & - & $2(1.7)$ \\
\hline Bacillus cereus & - & - & $2(66.7)$ & $1(33.3)$ & - & $3(2.6)$ \\
\hline \multicolumn{5}{|c|}{ Total } & 25 & 115 \\
\hline
\end{tabular}

The table 2 shows the type and frequency and percentage of microorganisms isolated in the four locations. The standard primary and secondary microbial identification procedures conducted on the CMT positive mammary gland secretion (milk samples) of lactating sheep and goats has revealed the isolation of twenty common bacterial organisms. In clinical mastitis, Staphylococcus aureus were the most prevalent pathogens with prevalence rate of $36.0 \%$ followed by E. coli $(20.0 \%)$, Staphylococcus epidermidis and Streptococcus agalactiae (12.0\%) each, Streptococcus dysgalactiae (8.0\%), and the least isolated bacteria were Staphylococcus chromogenes, Klebsiella pneumonia and Proteus vulgaris with prevalence of $4.0 \%$ each. On the other hand, in small ruminants with subclinical mastitis, S. aureus and E.coli were the most predominant isolates with prevalence rate of $18.3 \%$ 
followed by Strep. agalactiae (13.9\%), Strep. dysgalactiae (6.1\%), and the least isolated microorganisms were bacteria of different species including: Coagulase Negative Staphylococcus (CoNS) - auricularis, chromogenes, caprae and hyicus; Streptococcus pluranimalium, uberis and ruminatorum; Enterobacter cloacae, Klebsiella oxytoca, Klebsiella pneumonia, Morganella morganii, Salmonella typhimurium, Proteus vulgaris, Citrobacter freundii and Bacillus cereus with the prevalence rate of $4.3 \%$ and below (Table 2).

\section{DISCUSSION OF RESULTS}

Small ruminants farming play an important role in the economic development of people in Nigeria, especially those in the rural areas. In Nigeria, the number of farms of dairy goat and sheep is increasing annually. An important task in these farms is to obtain the maximum amount of products and preserve the health of animals. Although the rearing of small ruminants is easy, affordable, less labor-intensive than cow, it is highly profitable, it is seriously hampered by various diseases, firstly mastitis. Inflammation of the mammary gland (mastitis) in small ruminants is predominantly subclinical (Contreras et al., 2007).

The prevalence of subclinical mastitis in sheep (16.7\%) reported in this study is in close agreement with previous findings of Okoli et al. (2006) who reported $15.5 \%$ prevalence in ewes recorded in abattoir in Imo State, south-eastern Nigeria. According to the current investigation, the total prevalence of subclinical mastitis in goats $(24.6 \%)$ and this is higher than in most of the previous studies carried out in the last 20 years in Nigeria, were the scores are between 10-19.1\% [3,12,17], and this is in close agreement with the results reported in other countries of the world like $25.6 \%$ in Yathui/Wamunyu ward in Kenya [9]. However, the present finding is lower than the prevalence reported by other researchers in Nigeria (47.6 \% by Alawa et at. (2000) in Zaria, Kaduna State (Nigeria). Similarly, the average percentage prevalence of clinical mastitis in small ruminants - sheep and goats (5.7 $\%$ ) could not be compared due to lack of similar reports in small ruminants in the available literatures under Nigeria. However, these findings support the report of Sakar et al. (2011) who reported in other countries of the world (Bangladesh) prevalence of clinical mastitis in goats to be $5.27 \%$, but higher than the prevalence reported by other workers in Dagestan $1.57 \%$ by Aliev et al. (2013) and in Kenya $-1.9 \%$ by Laban N.M. (2017).

Staphylococcus was the most predominant isolate in our study which accounted for about 36.0 and $18.3 \%$ of the bacterial isolated in clinical and subclinical mastitis, respectively. This finding is in accordance with the literature and previous reports (Tambuwal et al. 2017; Alawa et al. 2000), E. coli and Streptococcus agalactiae were the second predominant isolates with prevalence rate of $20.0 \%$ and $12.0 \%$ in clinical mastitis and $13.9 \%$ and $18.3 \%$ in subclinical mastitis, respectively.

\section{CONCLUSION}

From the present study, it was concluded that the goats were more affected with both clinical and subclinical form of mastitis than sheep. At the same time, the prevalence occurrence of subclinical form of mastitis is 3-4 times greater than the clinical form. Moreover, mastitis in dairy small ruminants caused by bacterial microorganisms is very high $(36.0 \%)$ in the study areas, followed by E. coli and Streptococcus spp. These organisms were found as the most predominant species that could be associated with other bacterial species that caused infection in the udders of small ruminants - sheep and goats. Present results suggested good attention and management practices to control or prevent the occurrence of the disease.

\section{REFFERENCES}

1. Alawa J. P., Ngele M. B., Ogwu D. Chronic caprine mastitis in Nigerian goat breeds: microbiological flora and histopathological findings // Small Ruminant Research. - 2000. №35. - pp. 203-207 
2. Aliev A.Yu., Magomedov M.Z., Bulatkhanov B.B. Monitoring of mastitis in sheep in farms of RD // Veterinary pathology. - 2013. - №2. - pp. 5-7

3. Ameh J.A., Gyang E.O. Prevalence of clinical mastitis and intramammary infections in Nigerian goats. Preventive Veterinary Medicine. 1993 Vol. 17. Issues 1-2. P.- 41-46

4. Contreras A., Sierra D., Sanchez A., Corrales J.C., Marco J.C., Paape M.J., Gonzalo C. Mastitis in small ruminants // Small Ruminant Research. - 2007. - №68. - pp. 145-153.

5. Danmallam F. A., Pimenov N. V., Species composition of microflora isolated from the mammary gland of a healthy and sick mastitis goat // Veterinariya i zootekhniya. - 2017. №4. - pp. 6-12

6. Danmallam FA, Shikhbabaev E.U. The main pathogens for goat mastitis // Materials of the Xth International Student Scientific Conference "Actual problems of infectious pathology and biotechnology". - 2017. - №1. - pp. 22-24.

7. Haftay A., Habtamu T. M., Abebe M. S. Bacterial identification and antimicrobial susceptibility of subclinical mastitis causing bacteria from goats in Aba'lla district, Afar, North-Eastern Ethiopia// Revue Méd. Vét. - 2016. -№167 (7-8). - pp.170-175

8. Islam M. A., Samad M. A., Anisur Rahman A. K. M. Bacterial pathogens and risk factors associated with mastitis in black Bengal goats in Bangladesh // Bangl. J. Vet. Med. 2011. -№9(2). - pp. 155-159

9. Laban N.M. Prevalence of mastitis and associated risk factors in dairy goats in Machakos County, Kenya: Thesis Masters of Science - Nairobi, 2017. - 127 p.

10. Mbindyo C. M., Gitao C.G., Bebora L. A cross-sectional study on the prevalence of subclinical mastitis and antimicrobial susceptibility patterns of the bacterial isolates in milk samples of smallholder dairy goats in Kenya/l American Journal of Research Communication. - 2014. -№2(8). pp. 30-51

11. Ogbeh A. Nigeria releases census of goats, sheep, pigs, other livestocks in country/l Premium Times. - 2016. june 2, http://www.premiumtimesng.com/

12. Okoli I.C., Opara M.N., Iheukwumere F.C., Herbert U. Analysis of Abattoir records for Imo state, Nigeria from 1995 - 1999 IV: Incidence of Mastitis Amongs cattle, sheep and goats // Journal Of Agriculture and Social Research (JASR). - 2006. - №2(6). - pp. 65-72.

13. Quinn P.J., Markey B.K., Carter M.E., Donelly W.J., Leonard F.C. Bacterial cause of bovine mastitis. Veterinary Microbiology and Microbial Diseases, Blackwell Science Ltd, a Blackwell publishing company. - 2002. pp. 465-475

14. Sakar H., Samad M.A. Udder halve-wise comparative prevalence of clinical and subclinical mastitis in lactating goats with their bacterial pathogens and antibiotic sensitivity patterns in Bangladesh. Bangl. J. Vet. Med. (2011). 09 (2): - pp. 137-143

15. Shittu A, Chafe U. M., Buhari S., Junaidu A. U., Magaji A. A., Salihu M. D., Lawal M. D., Jibril A. An overview of mastitis in Sokoto red goat, Nigeria // Sokoto Journal of Veterinary Science. - 2008. -№7(1). - pp. 65-70

16. Tambuwal F.M., Jibrin A. Prevalence and antibiotic susceptibility pattern of Bacterial isolates from Red Sokoto Goats (Rsg) with subclinical mastitis in Sokoto North Local Government Area, Sokoto State, Nigeria // Scholarly Journal of Biological Science . 2017. - №6(3). - pp. 48-54.

17. Tanimomo B.K., Hena S.A., Ngbede E.O., Tarhyel R., Owoleke O.E. Prevalence of mastitis in goat herds in some northwestern villages in Nigeria // Scientific Journal of Veterinary Advances. - 2012. - №1(2). - pp. 52-56. 